\title{
PERAN KEPERCAYAAN DIRI TERHADAP PRESTASI BELAJAR MATEMATIKA SISWA
}

\author{
INTAN VANDINI \\ intanvandini25@gmail.com \\ Program Studi Teknik Informatika,Fakultas Teknik, Matematika, dan IPA Universitas \\ Indraprasta PGRI
}

\begin{abstract}
Abstrak. Pada hakikatnya, dunia pendidikan merupakan hal yang vital dalam menjalani kehidupan bermasyarakat, termasuk juga bagi perkembangan dan kemajuan suatu bangsa. Penddikan juga mempunyai pengaruh yang besar pada perubahan jalan hidup seseorang. Semenjak kita dilahirkan kita sudah mulai mendapatkan pendidikan, terutama dari keluarga. Banyak pihak yang sepakat bahwa keluarga adalah sekolah pertama bagi peserta didik. Pendidikan tidak berdiri dengan sendirinya, banyak faktor yang mempengaruhi proses terjadinya pendidikan. Salah satunya dalam menjalankan pendidikan diperlukan proses belajar. Proses belajar dan pembelajaran sangat membantu peserta didik untuk memperoleh ilmu pengetahuan yang bermanfaat. Dalam menjalani proses belajar dan pembelajaran di sekolah terdapat berbagai bidang ilmu, salah satunya adalah matematika. Matematika merupakan suatu ilmu yang penggunaannya dapatditemukan di berbagai bidang ilmu atau segi kehidupan manusia. Dalam meningkatkan prestasi belajar matematika peserta didik adalah kepercayaan diri. Kepercayaan diri ini harus dimiliki oleh masing-masing peserta didik. Pada kenyataannya, kepercayaan diri yang dimiliki masing-masing peserta didik masih relatif rendah. Hal ini terlihat dari rasa kepercayaan diri yang kurang pada saat mengerjakan soal-soal matematika atau pada saat maju ke depan kelas untuk mengerjakan soal di papan tulis. Para peserta didik masih sering melihat jawaban temannya hanya untuk mendapakan prestasi belajar matematika yang baik.
\end{abstract}

Kata Kunci: pendidikan, kepercayaan diri, himpunan, prestasi belajar matematika.

\begin{abstract}
In essence, education is vital to live a social life, as well as for the development and progress of a nation. Education also has a great influence on changing one's way of life. Since we are born we have started to get an education, especially of the family. Many parties agree that the family is the first school for students. Education does not stand by itself, a lot of factors that affect the process of education. One of them in carrying out the necessary education and learning..Teaching and learning process greatly assist learners to gain useful knowledge. In undergoing the process of teaching and learning in schools there are many fields of science, one of which is math. Mathematics is a science that its use in various fields of science or in terms of human life. In improving the learning achievement of students is confidence. This confidence must be owned by each learner._n fact, possessed the confidence of each learner is still relatively low. This is evident from the lack of a sense of confidence when working on math problems or the time to come forward to do the problems on the board. The students are still often see his answer only to can good learning achievement.
\end{abstract}

Keywords: Education, self-confidence, set, math achievement. 


\section{PENDAHULUAN}

Pendidikan mempunyai pengaruh yang besar pada perubahan jalan hidup seseorang. Menurut Syafinuddin al Mandari (2004: 65), pendidikan dilaksanakan bukan hanya sekedar untuk mengejar nilai-nilai, melainkan memberikan pengarahan kepada setiap orang agar dapat bertindak dan bersikap benar sesuai dengan kaidah-kaidah dan spirit keilmuan yang dipelajari. Berbagai upaya dilakukan untuk mendapatkan pendidikan, selain di dalam keluarga, pendidikan juga bisa diperoleh melalui sekolah. Disadari atau tidak matematika sering digunakan dalam kehidupan sehari-hari untuk menyelesaikan suatu masalah. Oleh sebab itu tidak heran jika konsep-konsep matematika digunakan pada berbagai ilmu pengetahuan lain, seperti ilmu fisika, kimia, teknik, ekonomi, dan lain-lain. Matematika adalah suatu bidang ilmu yang mempelajari besaran dan perhitungan dan merupakan studi besaran, struktur, ruang, dan perubahan. Sebenarnya matematika merupakan pelajaran yang berdaya guna tinggi, kebutuhan pemahaman dan penerapan matematika dalam kehidupan manusia menjadikannya sebagai salah satu mata pelajaran yang harus dipelajari di sekolah.

Pada kenyataannya, sebagian peserta didik masih kurang semangat ketika menghadapi pelajaran matematika. Peserta didik masih beranggapan bahwa matematika merupakan pelajaran yang sulit dan membosankan. Ada berbagai faktor penyebab peserta didik merasa kurang antusias ketika belajar matematika. Salah satunya karena matematika memiliki karakteristik yag khas yang berbeda dari pelajaran lain. Perbedaan itu antara lain, pembahasan mengandalkan nalar, artinya info awal berupa pengertian dibuat seefisien mungkin, melibatkan perhitungan operasi dan dapat dipakai dalam kehidupan sehari-hari.

Prestasi belajar matematika dipengaruhi oleh faktor internal dan eksternal. Faktor internal merupakan faktor yang berasal dari dalam diri sendiri, seperti motivasi, kecerdasan emosional, kepercayaan diri, kemandirian, dan lain-lain. Sedangkan faktor eksternal merupakan faktor yang berasal dari luar diri sendri, seperti sarana dan prasarana, lingkungan, guru, dan metode dalam mengajar. Salah satu faktor internal yang penting dalam meningkatkan prestasi belajar matematika adalah kepercayaan diri. Kepercayaan diri ini harus dimiliki oleh masing-masing peserta didik. Seperti yang dikatakan oleh Rakhmat (2000) bahwa " kepercayaan diri adalah rasa percaya terhadap diri sendiri yang dimiliki setiap individu dalam kehidupannya, serta bagaiman individu tersebut memandang dirinya secara utuh dan menagacu kepada konsep diri “. Hal ini didukung oleh pendapat Nurla Isna (2011: 60) bahwa “ kepercayaan diri merupakan sebuah kekuatan yang luar biasa laksana reaktor yang membangkitkan segala energy yang ada pada diri seseorang untuk mencapai sukses “. Sebagai generasi penerus bangsa, sikap percaya diri sangat penting ditanamkan pada peserta didik agar ia tumbuh menjadi sosok yang mampu mengembangkan potensi dirinya. Pada kenyataannya, kepercayaan diri yang dimiliki peserta didik masih relatif rendah. Hal ini terlihat dari rasa kepercayaan diri yang kurang pada saat mengerjakan soal-soal matematika atau pada saat maju ke depan kelas untuk mengerjakan soal di papan tulis. Para peserta didik masih sering melihat jawabannya temannya sendiri bahkan mengandalkan jawaban temannya hanya untuk mendapatkan prestasi belajar yang baik.

Banyak peserta didik yang merasa tidak percaya diri pada jawabannya, padahal jawabannya belum tentu salah. Sebagian peserta didik mempunyai persepsi yang salah, mereka sekolah hanya untuk mendapatkan nilai yang baik, padahal hakikatnya mereka sekolah untuk menuntut ilmu yang bermanfaat. Oleh karena itu, cara apapun mereka lakukan termasuk menyontek demi mendapatkan nilai matematika yang baik. Sebuah kepercayaan diri juga dapat menimbulkan rasa optimis sehingga secara otomatis semangat dalam belajar matematika akan muncul. Kepercayaan diri dapat distimulus dari 
luar peserta didik. Misalnya , melalui pemberian penghargaan kepada peserta didik yang berhasil.

Berdasarkan hasil analisis masalah di atas, dapat dilakukan penelitian dan rumusan masalahnya untuk mengetahui pengaruh kepercayaan diri peserta didik terhadap prestasi belajar matematika. Dengan demikian, pencapaian prestasi belajar dapat dibuktikan.

\section{PEMBAHASAN}

\section{Pembelajaran dan Pendidikan}

Pada dasarnya belajar merupakan suatu kegiatan internal yang sangat kompleks. Belajar dilakukan untuk mendapatkan ilmu pengetahuan, pemahaman, dan informasi bermanfaat yang dilaksanakan secara formal maupun informal. Oleh karena itu, belajar harus mencapai sasaran yang dituju. Para ahli berbeda pendapat dalam mendefinisikan tentang arti belajar itu sendiri. Perbedaan tersebut dikarenakan bentuk dalam belajar itu beraneka ragam. Seperti belajar menghafal lagu, menghitung, dan menyelesaikan soalsoal matematika merupakan suatu pembelajaran.

Menurut kamus saku Bahasa Indonesia (2010: 38), bahwa “ belajar adalah berusaha, berlatih untuk mendapatkan pengtahuan “. Maksud yang diungkapkan dari kamus tersebut adalah belajar merupakan suatu kegiatan yang memerlukan usaha dan latihan yang intensif agar mendapatkan pengetahuan dan informasi yang penting. Seperti yang dijelaskan Daryanto (2009: 2), “ belajar adalah suatu proses usaha yang dilakukan seseorang untuk memperoleh suatu perubahan tingkah laku yang baru secara keseluruhan “. Maksud yang diungkapkan oleh Daryanto di atas adalah bahwa belajar suatu kegiatan yang melibatkan usaha dari individu untuk mengubah pola perilaku secara menyeluruh dalam menyesuaikan interaksi dengan lingkungan. Dimyati dan Mudjiono (2006: 156) berpendapat " belajar adalah proses melibatkan manusia secara orang per orang sebagai suatu kesatuan organism sehingga terjadi perubahan pada pengetahuan, keterampilan, dan sikap “. Dimyati dan Mudjiono bermaksud menyampaikan bahwa belajar merupakan suatu perubahan pengetahuan, perilaku yang melibatkan individu secara pribadi. Sutikno (2007: 5) mempunyai pendapat bahwa “ belajar merupakan suatu proses usaha yang dilakukan oleh seseorang untuk memperoleh suatu perubahan yang baru sebagai hasil pengalamannya sendiri dalam interaksi dengan lingkungannya “. Sutikno ingin menyampaikan bahwa belajar merupakan proses usaha yang dilakukan seseorang dalam mendapatkan perubahan baru dari pengalamannya berinteraksi dengan lingkungannya. Pendapat yang sama juga diungkapkan oleh Sanjaya (2008: 229), “ belajar adalah suatu proses aktivitas mental seseorang dalam berinteraksi dengan lingkungannya sehingga menghasilkan perubahan tingkah laku yang bersifat positif “. Dari pendapat di atas dijelaskan bahwa belajar adalah proses mental seseorang yang terjadi ketika berinteraksi dengan lingkungannya yang dapat menghasilkan perubahan tingkah laku yang postif dalam berbagai aspek.

Sementara Witherington (Syaodih, 2007: 155) menyampaikan bahwa “ belajar merupakan perubahan dalam kepribadian yang dimanifestasikan sebagai pola-pola respons yang baru yang berbentuk keterampilan, sikap, kebiasaan, pengetahuan, dan kecakapan “. Menurut pendapat di atas dapat disampaikan bahwa belajar merupakan proses perubahan tingkah laku atau kepribadian secara menyeluru oleh individu tersebut. Ahmadi dan Supriyono (2004: 128) menjelaskan yaitu “ belajar adalah suatu proses usaha yang dilakukan individu untuk memperoleh suatu perubahan tingkah laku yang baru. Ahmadi dan Supriyono bermaksud menyampaikan bahwa belajar membutukan suatu usaha yang sungguh-sungguh untuk mendapatkan pengetahuan yang baru. Walaupun para ahli berpendapat tentang definisi belajar, namun ada kesamaan dalam 
pendapat mereka, yaitu dalam hal mengembangkan dirinya kea rah sebuah peningkatan dari keadaan sebelumnya dan mengalami suatu perubahan yang lebih baik.

Jadi, dapat disimpulkan dari keseluruhan pendapat yang telah diungkapkan para ahli bahwa belajar adalah suatu proses perubahan individu baik tingkah laku maupun perkembangan pada pengetahuan ataupun pribadi yang didasari dari sebuah usaha dalam mencapai suatu tujuan dalam berinteraksi dengan lingkungannya.

\section{Prestasi Belajar}

Seorang peserta didik dalam kegiatan belajar pasti ada tujuan dan harapan yang ingin dicapai, salah satunya adalah prestasi belajar yang baik. Misalnya, seorang peserta didik mempelajari matematika setiap hari dengan tujuan jangka pendeknya agar ia dapat menguasai matematika. Namun dalam tujuan jangka panjangnya, peserta didik mengharapkan prestasi belajar matematika yang tinggi. Prestasi belajar yang diperoleh dari hasil belajar adalah bentuk prestasi akademis sebagai bukti tertulis pencapaian pemahaman seorang peserta didik terhadap mata pelajaran yang dipelajari dalam kurun waktu tertentu. Prestasi belajar adalah sebuah kaliat yang terdiri dari dua kata yaitu prestasi dan belajar. Antara kata prestasi dan belajar mempunyai arti yang berbeda.

Oleh karena itu, sebelum pengertian prestasi belajar, ada baiknya pembahasan ini diarahkan pada masing-masing permasalahan terlebih dahulu untuk mendapatkan pemahaman lebih jauh mengenai makna kata prestasi dan belajar. Di bawah ini akan dikemukakan beberapa pengertian prestasi belajar menurut para ahli. Seperti yang dikatakan Anne Ahira (2011) bahwa " prestasi belajar dan proses belajar adalah satu kesatuan yang tidak dapat dipisahkan karena prestasi belajar pada hakikatnya adalah hasil akhir dari sebuah proses belajar “. Anne Ahira ingin menyampaikan bahwa prestasi belajar dan proses belajar sangat berkaitan erat dan untuk mengetahui prestasi belajar seorang peserta didik biasanya dilakukan evaluasi terhadap materi yang diberikan.

Sebuah prestasi akademik tidak bisa dijadikan jaminan dalam mencapai masa depan yang cemerlang. Hal ini disebabkan karena berbagai faktor, yaitu cara belajar atau proses belajar seorang peserta didik berbeda-beda dan para peserta didik lebih memfokuskan pada pengetahuan akademik sehingga melupakan soft skills, keterampilan dan keahlian.

Menurut kamus besar besar Bahasa Indonesia (2003: 700) bahwa prestasi belajar ialah penguasaan pengetahuan atau keterampilan yang dikembangkan oleh mata pelajaran, lazimnya ditunjukkan dengan nilai tes atau angka yang diberikan guru. Maksud yang ingin disampaikan dari isi kamus tersebut adalah prestasi belajar diperoleh dari proses belajar untuk menguasai ilmu pengetahuan yang biasa dikembangkan dan biasanya prestasi tersebut ditunjukkan dengan angka. Sementara itu, prestasi belajar dipengaruhi oleh faktor di luar diri peserta didik dan faktor di dalam diri peserta didik. Salah satu faktor di dalam diri adalah kepercayaan diri, sedangkan faktor di luar diri peserta didik misalnya adalah lingkungan. Penilaian terhadap prestasi belajar adalah merupakan tolak ukur keberhasilan dalam proses belajar dan pembelajaran yang telah dilakukan.

Faktor-faktor yang mempengaruhi prestasi belajar:

1. Faktor dari dalam diri peserta didik (intern), antara lain:

a. Faktor jasmani seperti faktor kesehatan dan cacat tubuh

Faktor kesehatan

Faktor kesehatan sangat berpengaruh terhadap proses belajar peserta didik, jika kesehatan seorang peserta didik terganggu atau cepat lelah, kurang bersemangat maka akan berpengaruh terhadap prestasi belajarnya. 


\section{Cacat tubuh}

Cacat tubuh adalah sesuatu yang menyebabkan kurang baik atau kurang sempurnanya tubuh.

b. Faktor psikologis seperti intelegensi, perhatian, bakat, minat, motivasi, kematangan, dan kesiapan.

Intelegensi

Slameto (2003: 56) mengemukakan intelegensi adalah kecakapan yang terdiri dari tiga jenis yaitu kecakapan untuk menghadapi hal yang baru, mengetahui relasi dan mempelajarinya dengan cepat.

Perhatian

Perhatian adalah keaktifan jiwa yang bertujuan semata-mata kepada suatu benda ataupun objek.

Bakat

Bakat adalah kemampuan untuk belajar. Kemampuan itu akan terealisasi pencapaian kecakapan yang nyata sesudah belajar atau terlatih.

Minat

Minat adalah menyangkut aktivitas-aktivitas yang dipilih secara bebas oleh individu. Minat besar pengaruhnya terhadap aktivitas belajar peserta didik.

Motivasi

Motivasi erat sekali hubungannya dengan tujuan yang akan dicapai dalam belajar, disadari atau tidak untuk mencapai tujuan perlu berbuat.

Kematangan

Kematangan adalah suatu fase dalam pertumbuhan seseorang.

Kesiapan

Kesiapan adalah kesediaan untuk memberikan respons atau reaksi.

c. Faktor kelelahan seperti kelelahan jasmani dan rohani.

Kelelahan jasmani

Terlihat dengan lemah lunglainya tubuh dan timbul kecenderungan untuk membaringkan tubuh.

Kelelahan rohani

Kelelahan rohani dapat terus menerus karena memikirkan masalah, mengerjakan sesuatu dengan terpaksa.

2. Faktor luar diri peserta didik (ekstern), antara lain:

a. Faktor keluarga seperti cara orang tua mendidik, relasi antar anggota keluarga, dan keadaan keluarga.

b. Faktor sekolah seperti guru dan cara mengajar, model pembelajaran, dan alatalat pelajaran.

3. Faktor lingkungan masyarakat seperti kegiatan peserta didik dalam lingkungan dan teman bergaul.

\section{Matematika}

Pada umumnya peristiwa-peristiwa yang kita alami selama ini setiap harinya banyak yang berhubungan dengan matematika. Misalkan mengukur luas tanah, mengukur tinggi badan, transaksi jual beli di pasar, dan lain-lain memerlukan perhitungan matematika. Namun dengan demikian sampai saat ini belum ada kesepakatan yang sesuai oleh para matematikawan mengenai arti yang tetap dari matematika tersebut. Hal ini disebabkan ruang lingkup matematika itu sendiri bersifat abstrak (tidak konkrit). Untuk dapat lebih memahami bagaimana hakikat matematika, kita dapat melihat dan memperhatikan pengertian istilah matematika dan beberapa definisi yang telah dijelaskan oleh para ahli. 
Kamus besar Bahasa Indonesia (Kustinah ,2010: 16), matematika adalah ilmu tentang bilangan-bilangan, hubungan antar bilangan, dan prosedur operasional yang digunakan dalam penyelesaian masalah mengenai bilangan. Sementara Manfaat (2010: 11) mempunyai pendapat bahwa matematika pada hakikatnya adalah suatu disiplin ilmu yang muncul dari sebuah proses peradaban manusia yang sangat panjang di bumi ini. Manfaat menambahkan matematika adalah pengetahuan yang disusun secara konsisten berdasarkan logika deduktif. Dari pendapat Manfaat dapat disimpulkan bahwa matematika merupakan suatu disiplin ilmu pengetahuan yang disusun secara konsisten dan diaplikasikan secara logis dan terarah.

Menurut Maswins (2010) bahwa matematika sampai saat ini belum ada kesepakatan yang bulat di antara para matematikawan tentang hakikat matematika itu sendiri. Sasaran penelaahan matematika tidaklah konkrit melainkan abstrak. Pada umumnya orang awam hanya akrab dengan satu cabang matematika elementer yang disebut aritmatika atau ilmu hitung dapat didefinisikan sebagai ilmu tentang berbagai bilangan yang bisa langsung diperoleh.

Dari beberapa pendapat para ahli di atas dapat disimpulkan bahwa matematika merupakan suatu ilmu struktur yang berkaitan dengan konsep abstrak. Ilmu matematika mempelajari pola atau simbol-simbol tertentu dan dapat digunakan di hampir semua cabang ilmu pengetahuan.

\section{Ruang Lingkup Teori Himpunan}

Objek suatu himpunan dapat berupa apapun yang penting dapat diterangkan dengan jelas. Misalnya zebra, rusa, gajah, dan harimau termasuk binatang menyusui, sedangkan ayam dan burung bukan binatang menyusui. Oleh karena itu dapat dikatakan binatang menyusui adalah himpunan. Berbeda dengan makanan enak. Makanan enak tidak dapat diterangkan dengan jelas. Oleh karena itu kita tidak dapat membuat himpunan dari makanan enak. Suatu himpunan dalam matematika dilambangkan dengan huruf capital.

Anggota himpunan adalah objek-objek yang membentuk suatu himpunan. Menyatakan suatu himpunan dapat dengan cara deskripsi yaitu cara menyatakan suatu himpunan dengan kata-kata dan cara tabulasi yaitu cara menyatakan himpunan dengan cara mendaftar anggota himpunan satu persatu.

\section{Prestasi Belajar Matematika}

Prestasi belajar matematika seorang peserta didik bagi sebagian orang hanya didefinisikan dan dilihat dari satu sisi. Sisi yang Nampak dan menjadi tolak ukur biasanya hanya pada nilai yang diperoleh seorang peserta didik dari ujian yang ditempuh baik ujian semester atau ulangan harian. Namun sebenarnya pengertian tersebut bukan hanya dilihat dari sudut pandang yang sempit tersebut. Nilai ujian bukan sebuah ukuran, apakah seorang peserta didik dikatakan berhasil atau tidak dalam mata pelajaran matematika. Nilai ujian hanyalah cerminan namun bukan satu-satunya alat ukur atau indicator tingkat keberhasilan peserta didik, karena nilai ujian bisa dimanipulasi. Oleh karena itu prestasi belajar matematika dapat diartikan perwujudan dari proses keberhasilan pembelajaran matematika yang dicerminkan dengan perubahan tingkah laku dalam bentuk kognitif, afektif maupun psikomotor peserta didik setelah mendapatkan pengalaman belajar matematika.

Pada dasarnya dalam proses pembelajaran ada beberapa kriteria sebagai alat ukur keberhasilan pendidikan. Ada 2 elemen yang menjadi indikator apakah seorang peserta didik mampu menguasai mata pelajaran matematika atau belum. Dengan indikator tersebut seorang peserta didik dapat lebih meningkatkan pemahaman tentang matematika. 
Indikator tersebut diantaranya pemahaman konsep dan pemahaman penalaran dan komunikasi. Untuk mengetahui kemampuan dan keberhasilan seorang peserta didik sebagai guru atau tenaga pengajar perlu melakukan penelitian yang berguna untuk mengetahui dan menilai sejauh mana peserta didik memahami materi yang diajarkan.

\section{Kepercayaan Diri}

Sebagai generasi penerus bangsa, sikap kepercayaan diri sangat penting ditanamkan pada diri seorang peserta didik agar ia tumbuh menjadi sosok yang mampu mengembangkan potensi dirinya. "Kepercayaan diri merupakan sebuah kekuatan yang luar biasa bagaikan reaktor yang membangkitkan segala energi yang ada untuk mencapai sukses (Nurla Isna ,2011: 60)”. Hakim (2002) berpendapat bahwa kelebihan yang ada di dalam diri seseorang harus dikembangkan agar menjadi produktif dan berguna bagi orang lain. Kepercayaan diri merupakan dasar dari motivasi diri untuk berhasil. Agar termotivasi seseorang harus percaya diri. Seseorang yang mendapatkan ketenangan dan kepercayaan diri haruslah menginginkan dan termotivasi dirinya. Banyak orang yang mengalami kekurangan tetapi bangkit melampaui kekurangan sehingga benar benar mengalahkan kemalangan dengan mempunyai kepercayaan diri dan motivasi untuk terus tumbuh. Kepercayaan diri merupakan suatu keyakinan dan sikap seseorang terhadap kemampuan pada dirinya sendiri dengan menerima secara apa adanya baik positif maupun negatif yang dibentuk dan dipelajari. Percaya diri adalah modal dasar seorang manusia dalam memenuhi berbagai kebutuhan sendiri. Seseorang mempunyai kebutuhan untuk kebebasan berpikir dan berperasaan sehungga seseorang yang mempunyai kebebasan berpikir dan berperasaan akan tumbuh menjadi manusia dengan rasa percaya diri. Salah satu langkah pertama dan utama dalam membangun rasa percaya diri adalah memahami dan meyakini bahwa setiap manusia memilki kelebihan dan kelemahan masing-masing.

Seperti yang diungkapkan Hakim (2002) rasa percaya diri tidak muncul begitu saja pada diri seseorang ada proses tertentu di dalam pribadinya sehingga terjadilah pembentukan rasa percaya diri. Hakim ingin mengungkapkan bahwa rasa kepercayaan diri harus terus dilatih dan dikembangkan agar bisa bermanfaat dalam kehidupan. Terbentuknya rasa kepercayaan diri yang kuat terbentuk melalui proses perkembangan yang melahirkan kelebihan-kelebihan tertentu, pemahaman-pemahaman seseorang terhadap kelebihan-kelebihan yang dimilikinya dan melahirkan keyakinan yang kuat, pemahaman dan reaksi positif terhadap kelemahan-kelemahannya yang dimiliki, dan pengalaman di dalam menjalani berbagai aspek kehidupan dengan menggunakan segala kelebihan yang ada pada dirinya. Beberapa cara yang ditempuh oleh guru untuk membangun karakter kepercayaan diri pada peserta didik yaitu:

a. Memberi pujian atas setiap pencapaian

Sesederhana apapun yang dilakukan oleh peserta didik, namun jika itu bernilai kebaikan, guru harus memberikan apresiasi berupa pujian.

b. Mengajari peserta didik untuk bertanggung jawab

Banyak hal yang dapat dilakukan oleh guru untuk menerapkan prinsip ini, seperti menugaskan peserta didik menjadi pembawa acara atau pemimpin rapat di kelas.

c. Mengajari peserta didik bersikap ramah dan senang membantu

Untuk mengajari peserta didik seperti itu guru harus selalu ramah terhadap siapapun sekaligus senantiasa tersenyum kepadanya.

d. Mengubah kesalahan menjadi bahan baku demi kemajuan

Saat peserta didik melakukan suatu kesalahan, guru harus tetap fokus pada kemajuan yang telah dicapainya, bukan pada kesalahan ataupun kegagalan yang dialaminya. 
Faktor -faktor yang mempengaruhi kepercayaan diri:

1. Faktor internal, meliputi:

a. Konsep diri

Terbentuknya rasa kepercayaan diri pada seseorang diawali dengan perkembangan konsep diri yang diperoleh dari suatu pergaulan kelompok. Pergaulan kelompok memberikan dampak yang positif juga dampak negatif.

b. Harga diri

Harga diri adalah penilaian yang dilakukan terhadap diri sendiri. Orang yang memiliki harga diri tinggi akan menilai dirinya secara rasional bagi dirinya serta mudah mengadakan hubungan dengan individu lain.

c. Kondisi fisik

Perubahan kondisi fisik juga berpengaruh pada kepercayaan diri. Fisik yang sehat dapat membantu peserta didik dalam meningkatkan kepercyaan diri yang kuat. Sedangkan fisik yang kurang baik menyebabkan peserta didik lemah dalam mengembangkan kepercayaan diri.

d. Pengalaman hidup

Kepercayaan diri diperoleh dari pengalaman yang mengecewakan karena dari pengalaman yang mengecewakan tersebut muncul rasa rendah diri sehingga nanti timbul kepercayaan diri yang kuat.

\section{Faktor eksternal}

\section{a. Pendidikan}

Pendidikan mempengaruhi rasa kepercayaan diri seseorang. Tingkat pendidikan yang rendah akan cenderung di bawah kekuasaan yang lebih pandai. Sedangkan individu yang pendidikannya lebih tinggi cenderung mandiri dan tingkat kepercayaan dirinya tinggi.

b. Pekerjaan

Bekerja dapat mengembangkan kreativitas dan rasa kepercayaan diri. Kepuasan dan rasa bangga didapat karena mampu mengembangkan diri.

c. Lingkungan dan pengalaman hidup

Lingkungan disini adalah lingkungan keluarga dan masyarakat. Dukungan yang baik diterima dari lingkungan keluarga seperti anggota keluarga yang berinteraksi dengan baik akan memberi rasa nyaman dan percaya diri yang tinggi. Dalam lingkungan masyarakat semakin bisa memenuhi norma dan diterima masyarakat.

\section{METODE}

Dalam penelitian ini menggunakan metode survey dengan teknik analisis deskriptif korelasi. Deskriptif artinya menjelaskan atau menerangkan suatu peristiwa, sedangkan korelasi adalah riset atau penelitian yang mencari ada atau tidak adanya pengaruh. Peneliti mengambil dua jenis data dalam penelitian ini. Dari kedua data tersebut terbentuk skor yang diperoleh dari data kepercayaan diri dan prestasi belajar matematika. Data kepercayaan diri diperoleh dari instrumen yang berbentuk kuisioner (angket) dan data prestasi belajar matematika diperoleh dari data instrumen prestasi belajar matematika peserta didik kelas VII semester genap dengan materi himpunan. Penelitian dilaksanakan di SMPN 208 Ciracas dalam waktu 4 bulan pada tahun 2012.

Teknik sampling yang digunakan dalam penelitian ini adalah random sampling, artinya dari tiap-tiap kelas diambil sebanyak 40 orang dengan menggunakan undian. Uji persyaratan analisis data dalam penelitian ini menggunakan uji normalitas untuk mengadakan pengujian terhadap normal atau tidaknya data yang akan di analisis, 
kemudian uji linieritas dilakukan untuk mengadakan pengujian linieritas regresi dengan uji F. Sedangkan pengujian hipotesis dengan koefisien korelasi, koefisien determinasi, persamaan regresi, uji signifikansi korelasi (uji T), dan uji signifikansi regresi.

\section{HASIL}

\section{Data Kepercayaan Diri}

Dari hasil pengukuran dari 40 siswa didapat skor maksimum 85 dan skor minimum 40,sehingga didapat rentangan 45. Hasil analisis data diperoleh mean sebesar 73,75,median sebesar 74,52, modus 74,52, dan simpangan baku 8,38.

\section{Data Prestasi Belajar Matematika}

Dari hasil pengukuran dari 40 siswa didapat skor maksimum 80 dan skor minimum 55,sehingga didapat rentangan 25. Hasil analisis data diperoleh mean sebesar 71,26,median sebesar 79.47, modus 79,52, dan simpangan baku 6,03.

\section{Uji Persyaratan Analisis Data}

Uji persyaratan analisis data menggunakan uji normalitas dan uji linieritas. Uji normalitas dengan menggunakan uji liliefors yang diperoleh hasil kedua variabel berdistribusi normal, sedangkan uji linieritas dengan bantuan tabel ANAVA yang didapat kedua variabel linier, sehingga dapat dilanjutkan uji statistik parametrik dengan korelasi dan regresi sederhana.

\section{Pengujian Hipotesis Penelitian}

Untuk mengetahui keeratan hubungan variabel $\mathrm{X}$ dan $\mathrm{Y}$ digunakan rumus korelasi product moment. Dari perhitungan didapat $r_{x y}=0,83$, artinya terdapat hubungan yang sangat kuat antara kepercayaan diri dengan prestasi belajar matematika.

Pengujian signifikansi korelasi diuji melalui uji hipotesis (uji t). Dari hasil perhitungan didapat $t$ hitung $=9,172$, sedangkan $t$ tabel $=2,021$, maka dapat disimpulkan terdapat hubungan yang signifikan antara kepercayaan diri terhadap prestasi belajar matematika.

Untuk mengetahui besarnya kontribusi pengaruh kepercayaan diri terhadap prestasi belajar matematika dilakukan dengan menghitung koefisien determinasi sebesar $68,89 \%$. Persamaan regrei yang terbentuk adalah $\mathrm{Y}=22,29+0,66 \mathrm{X}$.

Untuk pengujian keberartian regresi dilakukan dengan uji $\mathrm{F}$, diperoleh $\mathrm{F}$ tabel $=$ 4,10 dan $\mathrm{F}$ hitung $=5,46$, sehingga $\mathrm{F}$ hitung $>\mathrm{F}$ tabel berarti signifikan.

\section{Pembahasan Hasil Penelitian}

Berdasarkan hasil penelitian di atas jika peserta didik ingin memperoleh prestasi belajar matematika yang baik, maka yang harus dimiliki adalah kepercayaan diri yang baik pula. Mengingat pengaruh linear yang kuat antara kedua variabel ini maka peningkatan kepercayaan diri akan diikuti pula dengan peningkatan prestasi belajar matematika. Maka berdasarkan penelitian ini dapat diketahui bahwa pengaruh kepercayaan diri mempunyai pengaruh yang kuat terhadap prestasi belajar matematika.

\section{PENUTUP}

\section{Simpulan}

Berdasarkan hasil pembahasan di atas dapat disimpulkan bahwa kepercayaan diri terhadap prestasi belajar matematika mempunyai pengaruh yang kuat dan signifikan. Dengan demikian apabila peserta didik ingin memperoleh prestasi belajar yang baik 
diharapkan peserta didik memiliki kepercayaan diri yang baik pula. Peningkatan kepercayaan diri akan diikuti pula dengan peningkatan prestasi belajar matematika.

\section{Saran}

Dengan adanya pengaruh yang signifikan antar kepercayaan diri terhadap prestasi belajar matematika, maka peneliti mengemukakan saran sebagai berikut:

\section{Saran untuk guru}

a. Meningkatkan kemampuan teknik mengajar yang lebih inovatif dalam rangka meningkatkan kepercayaan diri peserta didik supaya peserta didik lebih terdorong semangatnya dalam mengejar prestasi.

b. Meningkatkan kemampuan dalam peningkatan kepercayaan diri peserta didik serta aplikasinya dalam prestasi belajar matematika.

c. Memberikan motivasi dan apresiasi yang tinggi terhadap peserta didik ketika peserta didik tersebut melakukan hal-hal yang baik.

d. Menciptakan suasana kelas yang nyaman sehingga ada interaksi yang baik antara peserta didik dan guru dalam proses belajar mengajar.

\section{Saran untuk sekolah}
a. Meningkatkan sarana dan prasarana yang dapat menunjang belajar dan pembelajaran.
b. Memberikan tambahan jam pelajaran di luar jam pelajaran sekolah untuk meningkatkan kepercayaan diri.
c. Memberikan arahan dan motivasi secara rutin sehingga timbul kepercayaan diri.

\section{DAFTAR PUSTAKA}

Abdillah, Plus dan Anwar Syarifuddin . 2010. Kamus Saku Bahasa Indonesia. Surabaya: Arkola.

Al Mandari, Syafinuddin. 2004. Rumahku Sekolahku. Jakarta: Pustaka Zahra.

Daryanto. 2009. Panduan Proses Pembelajaran Kreatif dan Inovatif. Jakarta: AV. Publishing.

Dimyati dan Mudjiono. 2006. Belajar dan Pembelajaran. Jakarta: Rineka Cipta.

Isna, Nurla. 2011. Panduan Menerapkan Pendidikan Karakter di Sekolah. Yogyakarta: Laksana.

Manfaat, Budi. 2010. Membumikan Matematika dari Kampus ke Kampung. Jakarta: Buku Kita.

Sanjaya, W. 2008. Kurikulum dan Pembelajaran. Jakarta: Kencana Media Grup.

Suprijono. 2009. Cooperative Learning: Teori dan Aplikasi PAIKEM. Jakarta: Pustaka Belajar.

Anne Ahira. 2010. Pengertian Kepercayaan Diri. http: //www.Anne Ahira.com/2010/06/Pengertian Kepercayaan Diri.html. diakses 7 Mei 2012. 